\title{
Morphologic Evolution of the Wilderness Area Breach at Fire Island, New York: 2012-15
}

By Cheryl J. Hapke, Timothy R. Nelson, Rachel E. Henderson, Owen T. Brenner, and Jennifer L. Miselis

Open-File Report 2017-1116

U.S. Department of the Interior U.S. Geological Survey 


\section{U.S. Department of the Interior \\ RYAN K. ZINKE, Secretary}

\section{U.S. Geological Survey \\ William H. Werkheiser, Acting Director}

U.S. Geological Survey, Reston, Virginia: 2017

For more information on the USGS—-the Federal source for science about the Earth, its natural and living resources, natural hazards, and the environment-visit https://www.usgs.gov/ or call 1-888-ASK-USGS (1-888-275-8747).

For an overview of USGS information products, including maps, imagery, and publications, visit https://store.usgs.gov/.

Any use of trade, firm, or product names is for descriptive purposes only and does not imply endorsement by the U.S. Government.

Although this information product, for the most part, is in the public domain, it also may contain copyrighted materials as noted in the text. Permission to reproduce copyrighted items must be secured from the copyright owner.

Suggested citation:

Hapke, C.J., Nelson, T.R., Henderson, R.E., Brenner, O.T., and Miselis, J.L., 2017, Morphologic evolution of the wilderness area breach at Fire Island, New York-2012-15: U.S. Geological Survey Open-File Report 2017-1116, 17 p., https://doi.org/10.3133/ofr20171116.

ISSN 2331-1258 (online) 


\section{Contents}

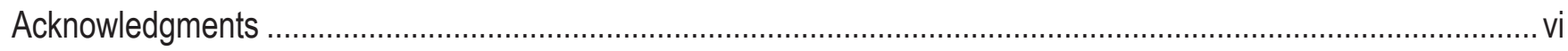

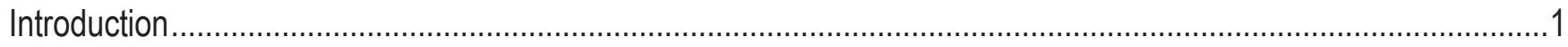

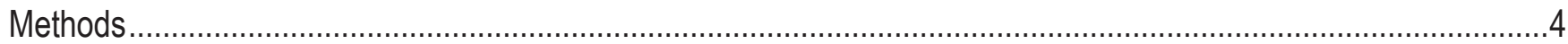

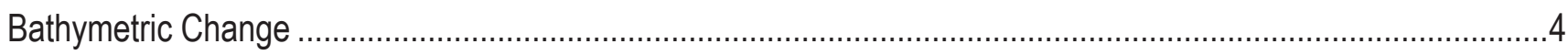

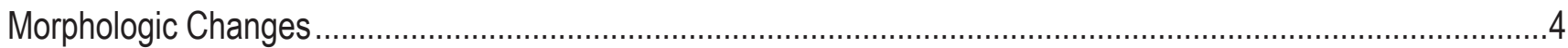

Seasonal Wave Climatology ……………...............................................................................................

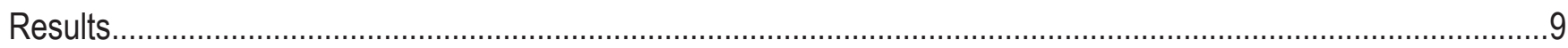

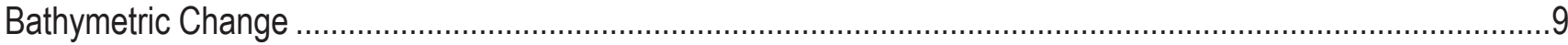

Shoreline and Width Change ............................................................................................................13

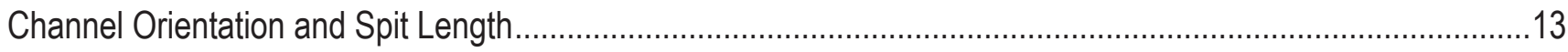

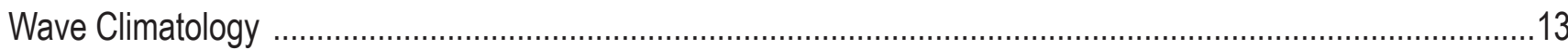

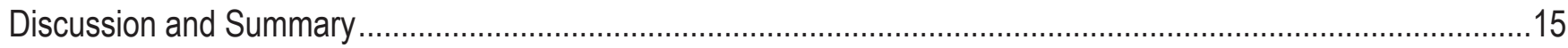

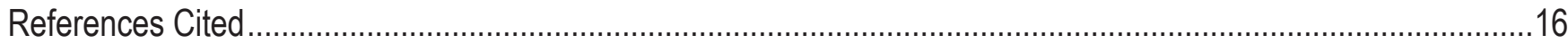

\section{Figures}

1. Location map of Fire Island, New York, showing the area where the wilderness breach formed during Hurricane Sandy.

2. $A$, Pre-storm and $B$, post-storm aerial photographs of the area where the breach formed after Hurricane Sandy, Fire Island, New York.

3. Aerial photographs showing $A$, the pre-storm location of an existing cross-island boardwalk and a manmade cut on the bay side of the island corresponding with $B$, where the breach formed and $C$, island topography prior to Hurricane Sandy

4. Map of U.S. Geological Survey-collected breach bathymetry for A, June 2013, B, June 2014, C, October 2014, and D, May 2015.

5. Description of breach metrics used to monitor breach evolution including transects used for calculating metrics, shorelines, breach width, channel orientation, and spit length

6. Aerial photographs of the breach from $A$, prior to the development of a sand spit on the northwestern side of the breach, and $B$, a developed and $C$, growing spit.

7. Rose diagrams of significant wave height and direction from WAVEWATCH III hindcast data, interpolated to the 20-meter isobath offshore of the breach for the period October 1, 2012, to October 31, 2015.

8. Aerial photographs overlain with elevation difference maps based on the available bathymetric data for the breach: A, pre-Hurricane Sandy to June 2013, no data were collected for the flood shoal; $B$, June 2013 to June 2014.

9. Aerial photographs overlain with elevation difference maps based on the available bathymetric data for the breach: A, June 2014 to May 2015; B, May 2015 to October 2015 
10. Plots showing cross-breach profiles for the $A$, northern, $B$, central, and $C$, southern portions of the breach channel with $D$, profile locations shown

11. Plots showing $A$, breach width and $B$, net western shoreline migration and $C$, eastern shoreline migration from November 2012 to November 2015 14

12. The time series of $A$, spit length and $B$, breach channel orientation, which indicates that the presence of the spit on the northwest side of the breach is closely associated with the orientation of the main breach channel and that it oscillates seasonally

\section{Tables}

1. Dates, types of surveys, and metrics for bathymetric data collected or extracted for the wilderness breach for the study period, 2012-15.

2. Overall and seasonal averages of wave height, period, and direction from the north for October 1, 2012, through October 31, 2015, from WAVEWATCH III hindcast data for Fire Island..... 


\section{Conversion Factors}

International System of Units to U.S. customary units

\begin{tabular}{lcl}
\hline \multicolumn{1}{r}{ Multiply } & By & \multicolumn{1}{c}{ To obtain } \\
\hline & Length & \\
meter $(\mathrm{m})$ & 3.281 & foot $(\mathrm{ft})$ \\
kilometer $(\mathrm{km})$ & 0.6214 & mile $(\mathrm{mi})$ \\
kilometer $(\mathrm{km})$ & 0.5400 & mile, nautical $(\mathrm{nmi})$ \\
meter $(\mathrm{m})$ & 1.094 & yard $(\mathrm{yd})$ \\
\hline
\end{tabular}

\section{Datum}

Vertical coordinate information is referenced to the North American Vertical Datum of 1988 (NAVD 88)]. Horizontal coordinate information is referenced to the North American Datum of 1983 (NAD 83)].

$\begin{array}{ll}\text { Abbreviations } \\ \text { DEM } & \text { digital elevation model } \\ \text { EAARL-B } & \text { Experimental Advanced Airborne Research Lidar B } \\ \text { GPS } & \text { Global Positioning System } \\ \text { HWL } & \text { high water line } \\ \text { lidar } & \text { light detection and ranging } \\ \text { MHW } & \text { mean high water } \\ \text { NPS } & \text { National Park Service } \\ \text { USACE } & \text { U.S. Army Corps of Engineers } \\ \text { USGS } & \text { U.S. Geological Survey } \\ \text { WW3 } & \text { WAVEWATCH III }\end{array}$




\section{Acknowledgments}

The authors are grateful to Chris Soller, Mike Bilecki, and Jordan Raphael with the National Park Service, Fire Island National Seashore, who provided permitting, access, and assistance with field logistics. We appreciate the effort of numerous U.S. Geological Survey (USGS) St. Petersburg Coastal and Marine Science Center (SPCMSC) and Pacific Science Center personnel who assisted with data collection and obtaining the required permits. We also would like to thank Jenna Brown, SPCMSC, and Alfredo Aretxabaleta, USGS Woods Hole Coastal and Marine Science Center, for their thorough and helpful reviews; and Betsy Boynton for enormous assistance with formatting figures. This work was funded by Hurricane Sandy supplemental project GS2-2B. 


\section{Morphologic Evolution of the Wilderness Area Breach at Fire Island, New York: 2012-15}

\section{Introduction}

Hurricane Sandy, which made landfall on October 29, 2012, near Atlantic City, New Jersey, had a significant impact on the coastal system along the south shore of Long Island, New York. A record significant wave height of 9.6 meters (m) was measured at wave buoy 44025 (National Oceanic and Atmospheric Administration, 2012), approximately 48 kilometers offshore of Fire Island, New York (fig. 1, inset). Surge and runup during the storm resulted in extensive beach and dune erosion (Hapke and others, 2013) and breaching of the Fire Island barrier island system at two locations, including a breach that formed within the Otis Pike Fire Island High Dune Wilderness area on the eastern side of Fire Island (figs. 1, 2).

The U.S. Geological Survey (USGS) has a long history of conducting morphologic change and processes research at Fire Island. One of the primary objectives of the current research effort is to understand the morphologic evolution of the barrier system on a variety of time scales (from storm scale

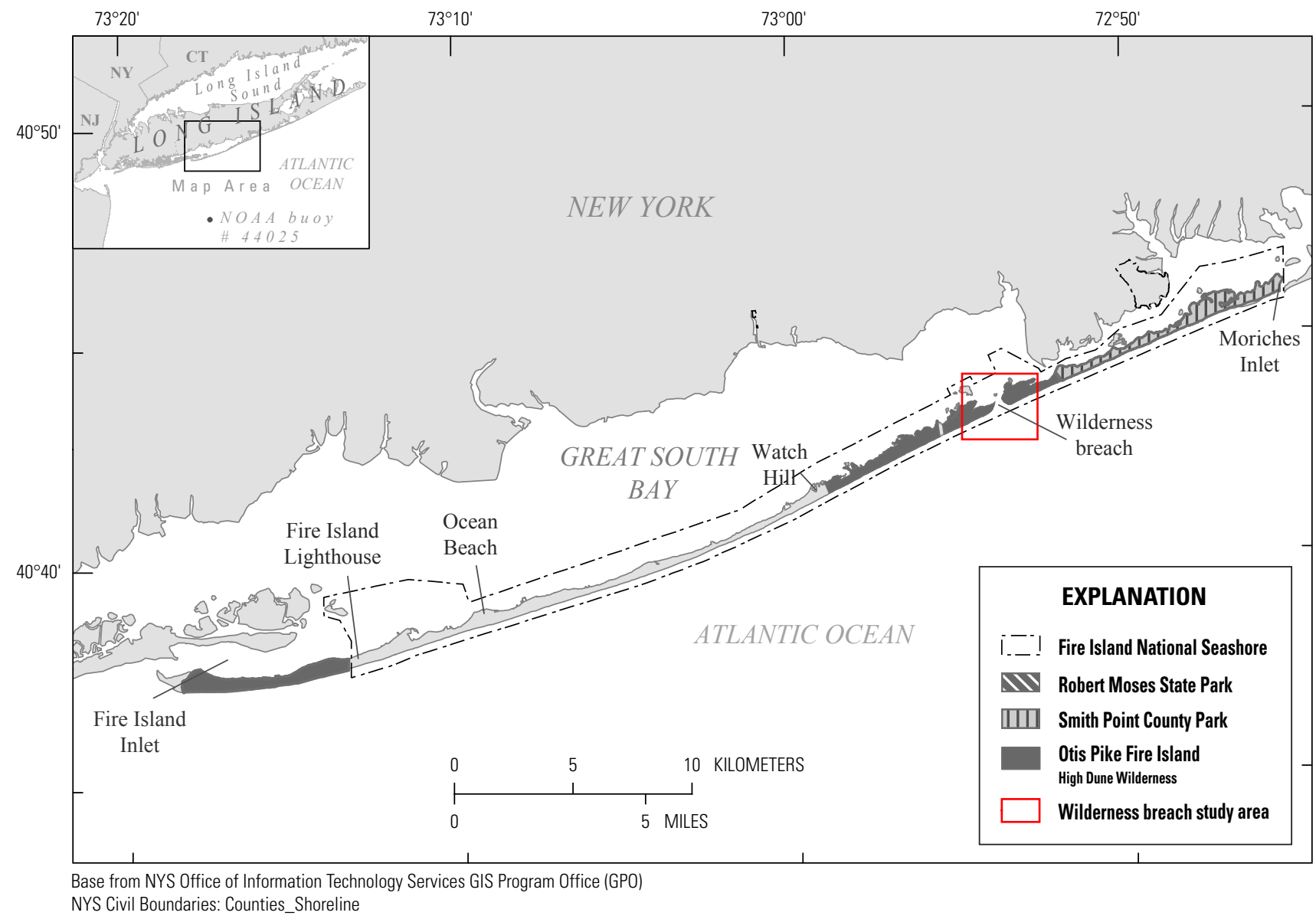

Figure 1. Location map of Fire Island, New York, showing the area where the wilderness breach formed during Hurricane Sandy. 


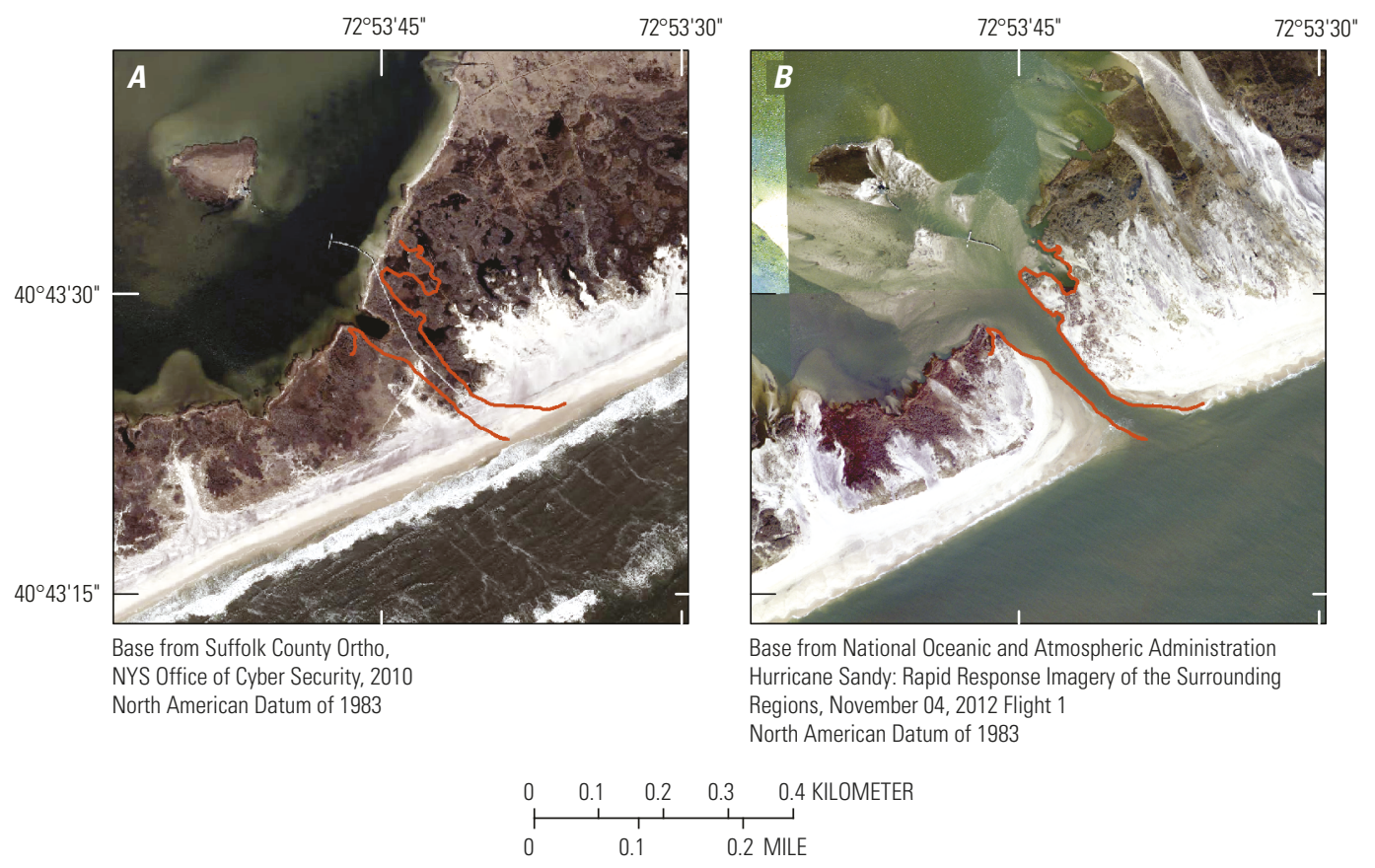

Figure 2. A, Pre-storm and $B$, post-storm aerial photographs of the area where the breach formed after Hurricane Sandy, Fire Island, New York.

to decade(s) to century). A number of studies that support the project objectives have been published (Hapke and others, 2010; Lentz and Hapke, 2011; Kratzmann and Hapke, 2012; Lentz and others, 2013; Schwab and others, 2013; Hapke and others 2016). Prior to Hurricane Sandy, however, little information was available on specific storm-driven change in this region. The USGS received Hurricane Sandy supplemental funding (project GS2-2B: Linking Coastal Processes and Vulnerability, Fire Island, New York, Regional Study) to enhance existing research efforts at Fire Island. The existing research was greatly expanded to include inner continental shelf mapping and investigations of processes of inner shelf sediment transport (Schwab and others, 2013, 2014; Warner, and others, 2014); beach and dune response and recovery (Hapke and others, 2013, 2015, 2016); and observation, analysis, and modeling of the newly formed breach in the Otis Pike High Dune Wilderness area (van Ormondt and others, 2015), herein referred to as the wilderness breach. The breach formed at the site of Old Inlet, which was open from 1763 to 1825 (Leatherman and Allen, 1985). The location of the initial island breaching does not directly correspond with topographic lows of the dunes, but instead the breach formed in the location of a cross-island boardwalk that was destroyed during Hurricane Sandy (fig. 3).

From 2013 to November 2015, bathymetric data were collected by the USGS St. Petersburg Coastal and Marine Science Center during three surveys of the breach channel and tidal shoals, and shoreline positions on each side of the breach (also collected by the National Park Service). Additionally, pre-storm topography/bathymetry EAARL-B light detection and ranging (lidar) data (Wright and others, 2014) were collected by the USGS the day prior to Hurricane Sandy's landfall. These data serve as a baseline for change analyses during four subsequent periods: June 2013 (Brownell and others, 2014), June 2014 (Nelson and others, 2016), October 2014 (Nelson and others, 2017a), and May 2015 (Nelson and others, 2017b). The June 2013 single-beam bathymetry data were collected in collaboration with the U.S. Army Corps of Engineers (USACE), using the Lighter Amphibious Resupply Cargo (LARC) vessel, and included the ebb shoal and breach channel. The USGS collected 

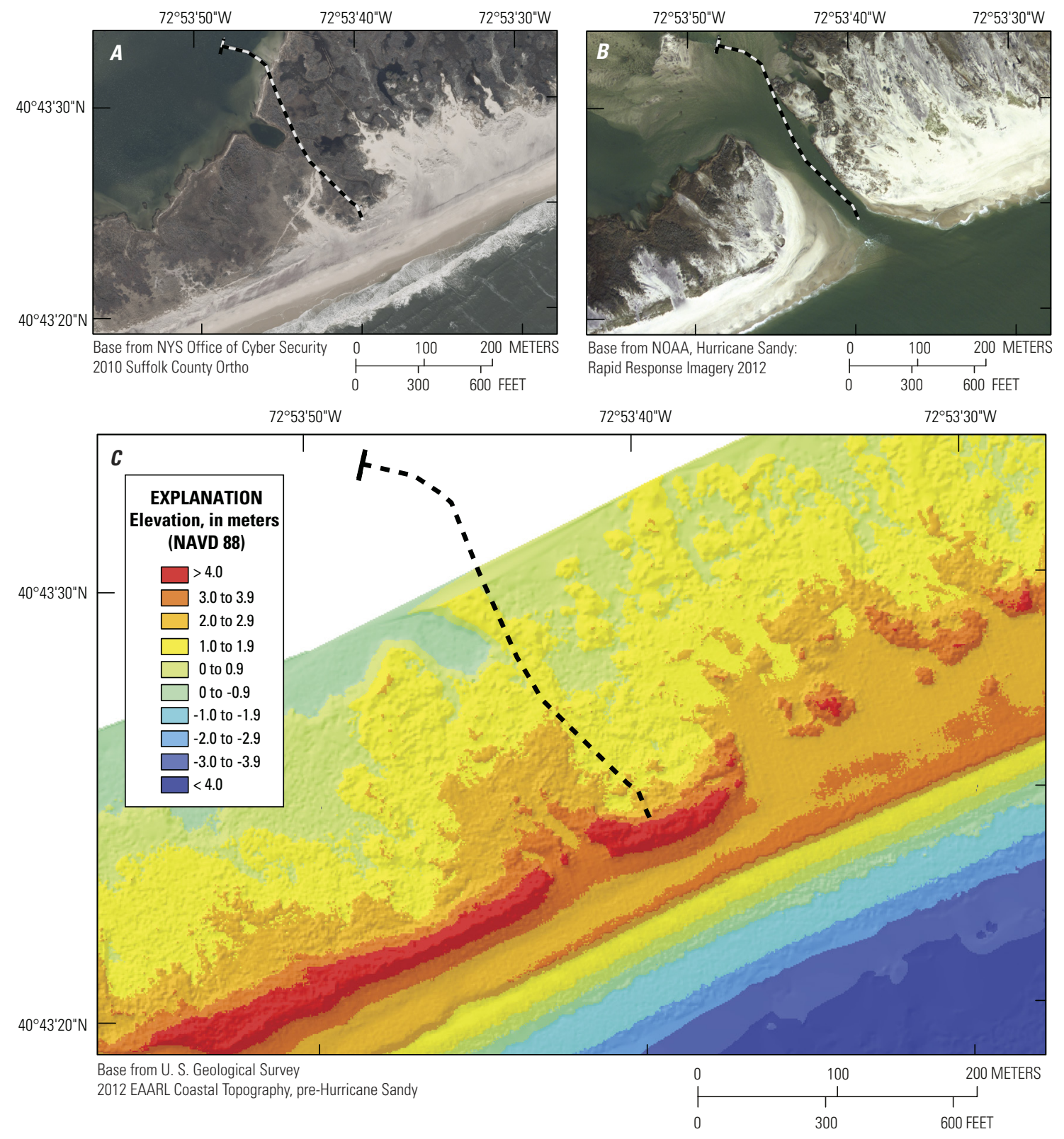

Figure 3. Aerial photographs showing $A$, the pre-storm location of an existing cross-island boardwalk and a manmade cut on the bay side of the island corresponding with $B$, where the breach formed and $C$, island topography prior to Hurricane Sandy. The topography shows that the breach formed in a location with higher dune elevations than the surrounding areas.

and processed the three additional bathymetric datasets using personal watercraft equipped with singlebeam echo sounders and backpack Global Positioning System (GPS) over shallow flood shoals.

Eastern and western breach shorelines were surveyed weekly to monthly beginning on November 6, 2012 (by the National Park Service [NPS], and USGS St. Petersburg Coastal and Marine Science Center), with measurements made every few weeks for the first year and every few months after October 2013. The NPS and researchers from Stony Brook University monitored the breach by collecting field data of the breach channel bathymetry, conducting aerial photographic overflights, and performing water-quality analyses (see http://po.msrc.sunysb.edu/GSB/). The aerial photography collected and rectified by Stony Brook University is used extensively in our morphologic change description to examine 
changes to breach shorelines (supplementing shoreline data collected in the field), channel width, and orientation. Due to the uncertainties and the variation in survey methods, a rigorous quantitative analysis was not performed. However, average calculations of various breach metrics allow a qualitative analysis of breach development and evolution.

This report presents an overview of the data collected and a summary discussion of the observed changes to the breach system and the seasonal wave climatology associated with the breach morphodynamic response.

\section{Methods}

\section{Bathymetric Change}

Digital elevation models (DEMs) were created from pre-storm bathymetric lidar data and poststorm bathymetric data (Brownell and others, 2014; Wright and others, 2014; Nelson and others, 2016, 2017a, b). Due to differences in survey point density, the DEM gridded cell size varied: $1 \mathrm{~m}$ for the 2012 EAARL-B lidar and the 2013 USGS-USACE survey, $25 \mathrm{~m}$ for the USGS June 2014 and May 2015 surveys, and $50 \mathrm{~m}$ for the USGS October 2014 survey. To qualitatively assess the morphologic changes to the flood and ebb shoals and the breach, channel difference plots were created using the "raster minus" functions in ArcMap. Morphologic change was determined by extracting the bathymetry along three cross-channel transects from the DEMs (fig. 4). Rates of change were calculated between each field survey, as well as net change from pre-storm to May 2015 (fig. 4). Due to changes in access and ability to collect data from time period to time period within the highly dynamic system, volumetric changes were not included in the analyses.

\section{Morphologic Changes}

The metrics used to quantify the morphologic change of the breach are from remote sensing and field data collection and include net shoreline migration, changes in breach width, changes in the length of a seasonally persistent spit on the western side of the breach, and the orientation of the primary discharge channel.

Breach shorelines were derived from three sources: alongshore mean high water (MHW) Digital GPS (DGPS) data collected by the USGS, alongshore DGPS data collected by the NPS (low water), and high water line (HWL) shorelines interpreted from aerial photography (table 1) (Henderson and others, 2017). The breach shoreline surveys were initiated shortly after the opening of the breach and provide a baseline for breach growth. The uncertainty with the shoreline position is high, due primarily to the inclusion of different proxies defining the shoreline position. The USGS shorelines (MHW) are likely higher on the beach than the NPS shorelines (low water) but lower than the HWL interpreted from the aerial photographs. Therefore, the results of this study are intended to describe broad trends of breach evolution and not to provide absolute positional information.

The breach metrics were calculated in Matlab by using a series of barrier island shore parallel transects (fig. 5, gray lines) spaced $5 \mathrm{~m}$ apart. Points on the eastern and western breach shorelines were selected at the intersection between transects and the shoreline. To prevent multiple intersecting points where a shoreline loops back, the westernmost intersection was used for the eastern shoreline, and the easternmost intersection was used for the western shoreline. Migration distance was determined as the displacement of each shoreline point relative to the first survey. A positive displacement indicates a westward migration; a negative displacement indicates an eastward migration. Width was calculated as the distance between matching eastern and western shoreline intersections along the same transect 


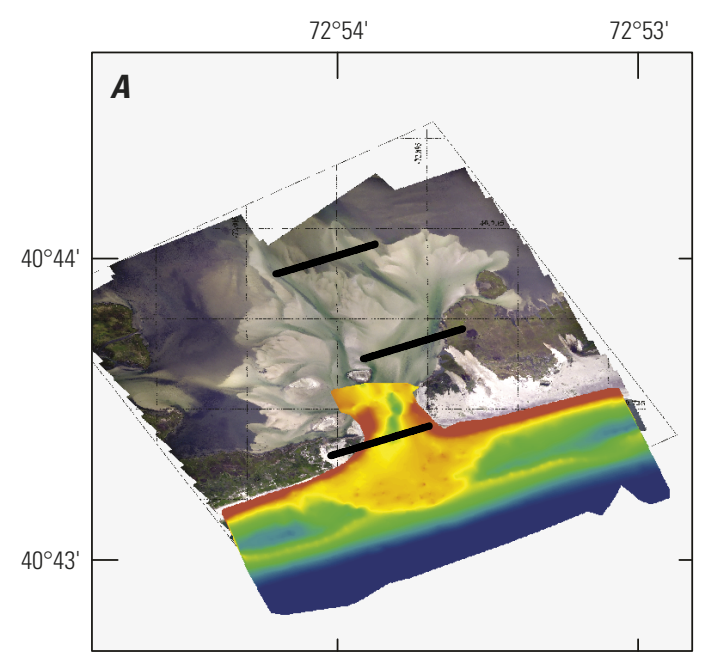

Base from SUNY Stony Brook Great South Bay Project June 16, 2013

North American Datum of 1983

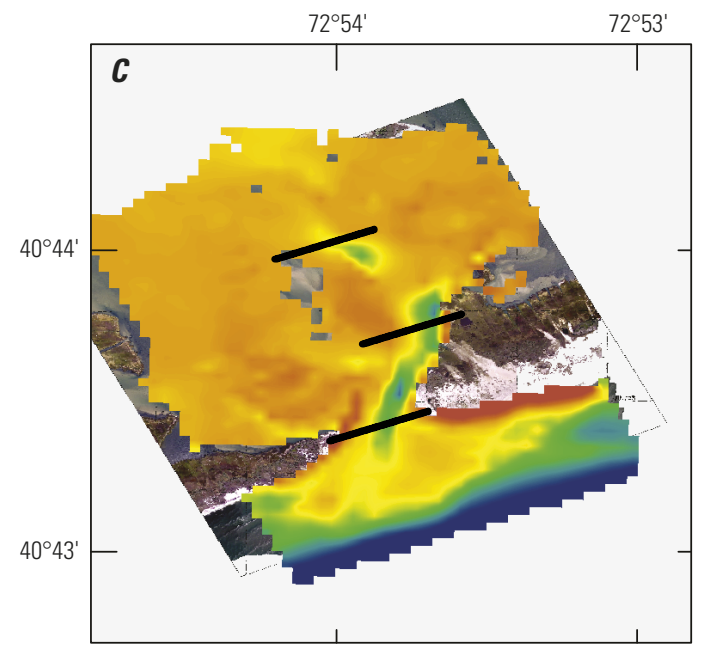

Base from SUNY Stony Brook

Great South Bay Project

September 26, 2014

North American Datum of 1983

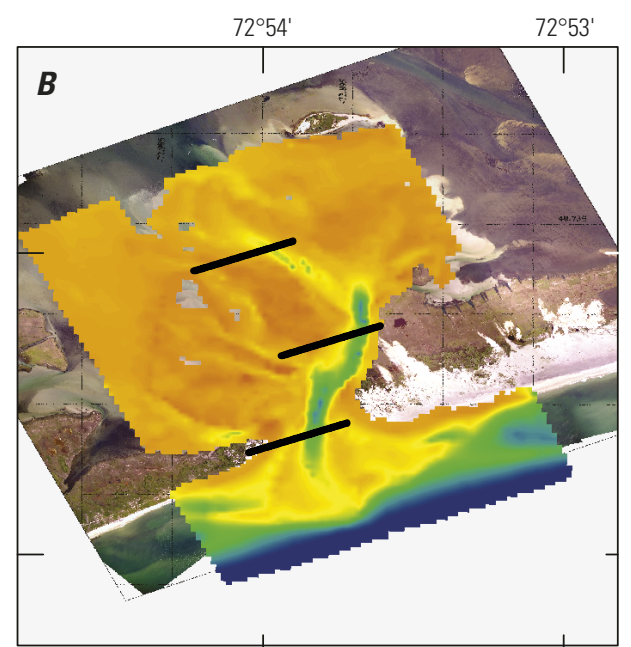

Base from SUNY Stony Brook

Great South Bay Project

June 24, 2014

North American Datum of 1983

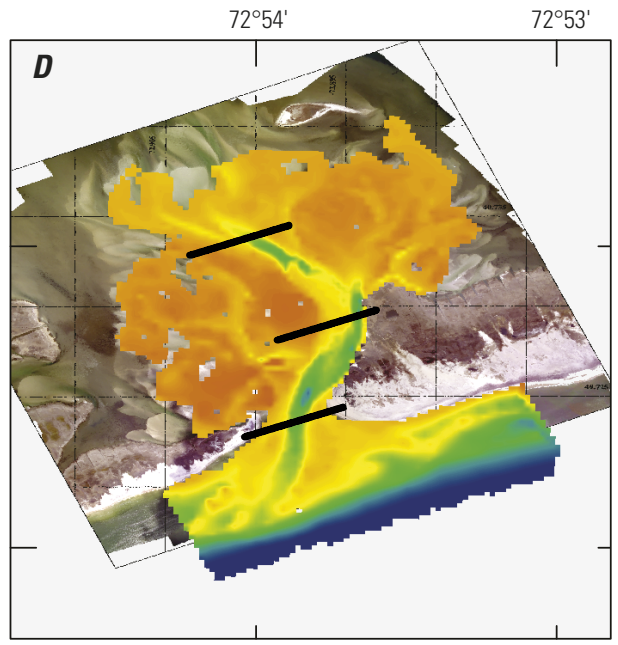

Base from SUNY Stony Brook

Great South Bay Project

April 26, 2015

North American Datum of 1983

Figure 4. Map of U.S. Geological Survey-collected breach bathymetry for A, June 2013, B, June 2014, C, October 2014, and $D$, May 2015.

(shoreline pair). The metrics are averages from each shoreline pair along the length of the breach, and the uncertainty represents the \pm 1 standard deviation of these values. The orientation of the breach is the slope of a line fit through the midpoint (average) between the western and eastern shoreline pairs.

On the western side of the breach, a north-northwest-oriented spit formed, evolved, and eroded over two seasonal cycles and appears to be correlated to changes in the orientation of the main discharge channel (fig. 6). In order to track the formation, growth, and erosion of the spit, aerial photographs (http://po.msrc.sunysb.edu/GSB/) were georectified in ArcMap, and the wet/dry shoreline of the spit was digitized. The spit was defined as the sandy extension from the vegetated backside of the barrier island to a point roughly along a shoreline pair on the breach channel side. The length of the spit was taken as the linear distance from the most southern baseline with an intersecting pair to the most northern pair (fig. 5). 
Table 1. Dates, types of surveys, and metrics for bathymetric data collected or extracted for the wilderness breach for the study period, 2012-15.

[lidar, light detection and ranging; GPS, Global Positioning System]

\begin{tabular}{|c|c|c|}
\hline Date & Data type & Metric \\
\hline Oct. 27,2012 & Topographic and bathymetric lidar & Shoreline, upper beach, shoreface \\
\hline Nov. 3-6, 2012 & GPS & Shoreline \\
\hline Nov. 10-11, 2012 & GPS & Shoreline \\
\hline Nov. $14-15,2012$ & GPS & Shoreline \\
\hline Jan. 3-4, 2013 & GPS & Shoreline \\
\hline Jan. 8-10, 2013 & GPS & Shoreline \\
\hline Jan. 15-17, 2013 & GPS & Shoreline \\
\hline Jan. 23-24, 2013 & GPS & Shoreline \\
\hline Jan. 27, 2013 & Aerial image & Shoreline and spit \\
\hline Jan. 30-31, 2013 & GPS & Shoreline \\
\hline Feb. 2, 2013 & Aerial image & Shoreline and spit \\
\hline Feb. 6-7, 2013 & GPS & Shoreline \\
\hline Feb. 13-14, 2013 & GPS & Shoreline \\
\hline Feb. 14, 2013 & Aerial image & Shoreline and spit \\
\hline Feb. 20-21, 2013 & GPS & Shoreline \\
\hline Feb. 26-28, 2013 & GPS & Shoreline \\
\hline Mar. 10, 2013 & Aerial image & Shoreline and spit \\
\hline Mar. 13-22, 2013 & GPS & Shoreline \\
\hline Mar. 27-28, 2013 & GPS & Shoreline \\
\hline Mar. 29, 2013 & Aerial image & Shoreline and spit \\
\hline Apr. 3-4, 2013 & GPS & Shoreline \\
\hline Apr. $10-11,2013$ & GPS & Shoreline \\
\hline Apr. 15-17, 2013 & GPS & Shoreline \\
\hline Apr. 17, 2013 & Aerial image & Shoreline and spit \\
\hline Apr. 23-24, 2013 & GPS & Shoreline \\
\hline May 1-2, 2013 & GPS & Shoreline \\
\hline May 6-7, 2013 & GPS & Shoreline \\
\hline May 12, 2013 & Aerial image & Shoreline and spit \\
\hline May 31, 2013 & Aerial image & Shoreline and spit \\
\hline June 16, 2013 & Aerial image & Shoreline and spit \\
\hline July 7, 2013 & Aerial image & Shoreline and spit \\
\hline Aug. 5, 2013 & Aerial image & Shoreline and spit \\
\hline Sept. 15, 2013 & Aerial image & Shoreline and spit \\
\hline Oct. 19, 2013 & Aerial image & Shoreline and spit \\
\hline Oct. 21-22, 2013 & GPS & Shoreline \\
\hline Nov. 4, 2013 & GPS & Shoreline \\
\hline Nov. 6, 2013 & Aerial image & Shoreline and spit \\
\hline Nov. 13-15, 2013 & GPS & Shoreline \\
\hline Dec. 8, 2013 & Aerial image & Shoreline and spit \\
\hline
\end{tabular}


Table 1. Dates, types of surveys, and metrics for bathymetric data collected or extracted for the wilderness breach for the study period, 2012-15.-Continued

[lidar, light detection and ranging; GPS, Global Positioning System]

\begin{tabular}{|c|c|c|}
\hline Date & Data type & Metric \\
\hline Dec. 19, 2013 & Aerial image & Shoreline and spit \\
\hline Jan. 21, 2014 & Aerial image & Shoreline and spit \\
\hline Feb. 20, 2014 & Aerial image & Shoreline and spit \\
\hline Mar. 17-Apr. 3, 2014 & GPS & Shoreline \\
\hline Mar. 24, 2014 & Aerial image & Shoreline and spit \\
\hline Apr. 22, 2014 & Aerial image & Shoreline and spit \\
\hline Apr. 24-25, 2014 & GPS & Shoreline \\
\hline May 18, 2014 & Aerial image & Shoreline and spit \\
\hline June 12-19, 2014 & GPS and single beam & Profiles \\
\hline June 24, 2014 & Aerial image & Shoreline and spit \\
\hline July 23-25, 2014 & GPS & Shoreline \\
\hline July 31, 2014 & Aerial image & Shoreline and spit \\
\hline Aug. 28, 2014 & Aerial image & Shoreline and spit \\
\hline Sept. 23-26, 2014 & GPS & Shoreline \\
\hline Sept. 26, 2014 & Aerial image & Shoreline and spit \\
\hline Oct. 5-10, 2014 & GPS and single beam & Profiles \\
\hline Oct. 7, 2014 & GPS & Shoreline \\
\hline Oct. 9-10, 2014 & GPS & Shoreline \\
\hline Oct. 30, 2014 & Aerial image & Shoreline and spit \\
\hline Nov. 30, 2014 & Aerial image & Shoreline and spit \\
\hline Dec. 14, 2014 & Aerial image & Shoreline and spit \\
\hline Dec. 29,2014 & Aerial image & Shoreline and spit \\
\hline Jan. 21, 2015 & GPS & Shoreline \\
\hline Feb. 28, 2015 & Aerial image & Shoreline and spit \\
\hline Mar. 19, 2015 & GPS & Shoreline \\
\hline Mar. 29, 2014 & Aerial image & Shoreline and spit \\
\hline Apr. 26, 2015 & Aerial image & Shoreline and spit \\
\hline May 13-19, 2015 & GPS and single beam & Profiles \\
\hline May 26, 2015 & Aerial image & Shoreline and spit \\
\hline June 30, 2015 & Aerial image & Shoreline and spit \\
\hline July 23, 2015 & Aerial image & Shoreline and spit \\
\hline July 29, 2015 & GPS & Shoreline \\
\hline Aug. 12, 2015 & Aerial image & Shoreline and spit \\
\hline Aug. 28, 2015 & Aerial image & Shoreline and spit \\
\hline Oct. 7, 2015 & Aerial image & Shoreline and spit \\
\hline Oct. 7-10, 2015 & GPS & Shoreline \\
\hline Nov. 24-27, 2015 & GPS & Shoreline \\
\hline
\end{tabular}




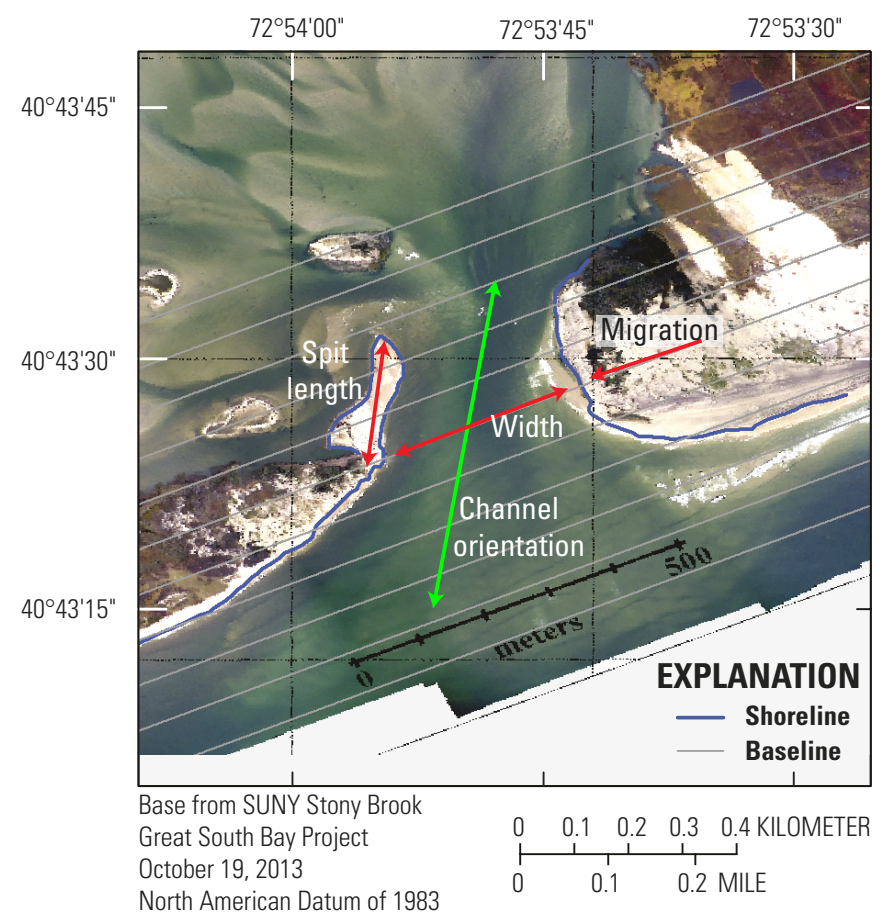

Figure 5. Description of breach metrics used to monitor breach evolution including transects (gray, only showing every $15^{\text {th }}$ baseline) used for calculating metrics, shorelines (blue), breach width (red arrow in breach channel), channel orientation (green arrow in breach channel), and spit length (red arrow on spit).

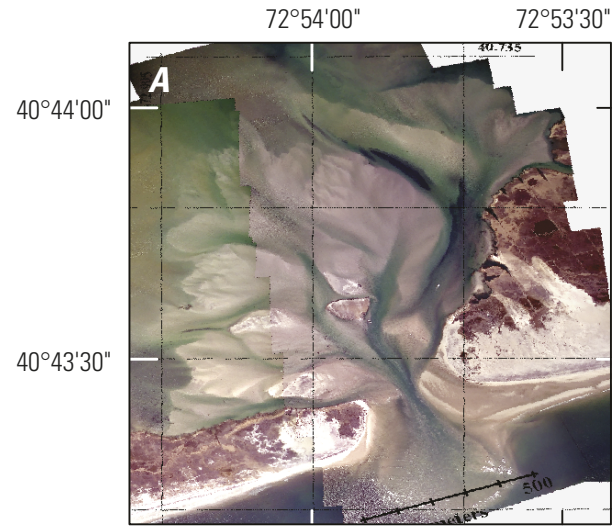

Base from SUNY Stony Brook Great South Bay Project March 29, 2013

North American Datum of 1983

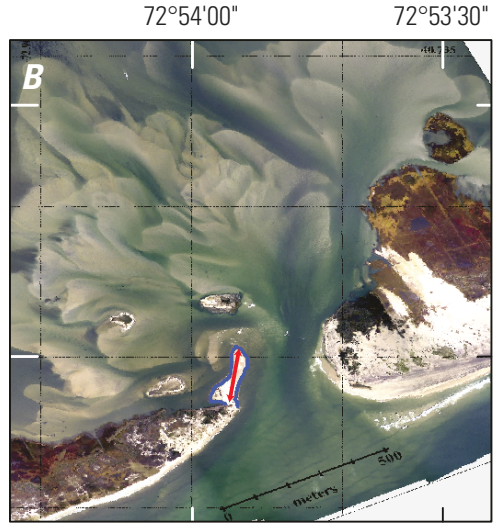

Base from SUNY Stony Brook

Great South Bay Project

October 19, 2013

North American Datum of 1983

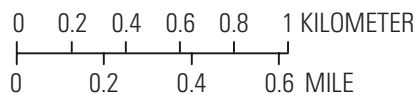

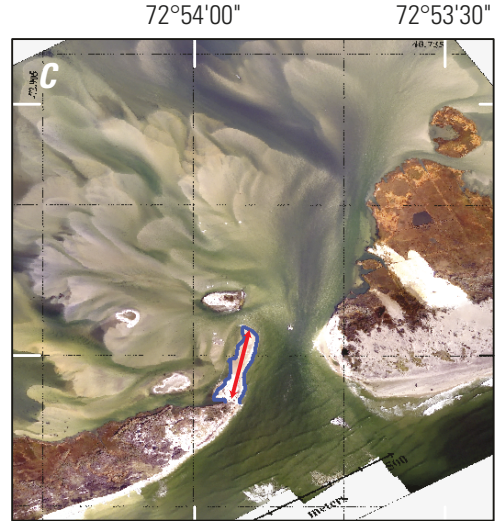

Base from SUNY Stony Brook

Great South Bay Project

November 6, 2013

North American Datum of 1983

Figure 6. Aerial photographs of the breach from $A$, prior to the development of a sand spit on the northwestern side of the breach, and $B$, a developed and $C$, growing spit. The growth of the spit corresponds to the development of a primary flood shoal channel along the western side of the breach. The red arrow in $B$ and $C$ indicates the length of the spit as measured in this analysis. 


\section{Seasonal Wave Climatology}

To examine the relation between the changes to the breach morphology and the processes driving change, wave direction and height were compiled from the National Oceanic and Atmospheric Administration WAVEWATCH III (WW3, http://polar.ncep.noaa.gov/waves/index2.shtml) hindcast data from October 1, 2012, to October 31, 2015 (table 2). Wave heights were interpolated to a point offshore of the breach at approximately the 20-m depth contour. The distribution of seasonal wave directions and heights are shown in rose diagrams in figure 7. Seasonal boundaries were defined as winter (JanuaryMarch), spring (April-June), summer (July-September), and autumn (October-December).

Table 2. Overall and seasonal averages of wave height, period, and direction from the north for October 1, 2012, through October 31, 2015, from WAVEWATCH III hindcast data for Fire Island (National Weather Service, 2009).

[The top 10 percent of wave heights and associated period and direction are shown in parentheses. m, meter; s, seconds; ${ }^{\circ} \mathrm{N}$, degrees north]

\begin{tabular}{lccccc}
\hline & Average & Winter & Spring & Summer & Autumn \\
\hline Height $(\mathrm{m})$ & 1.0 & $1.0(2.2)$ & $1.1(2.2)$ & $1.0(1.9)$ & $1.1(2.6)$ \\
Period $(\mathrm{s})$ & 7.9 & $7.4(8.7)$ & $7.7(8.1)$ & $8.5(8.7)$ & $8.3(9.8)$ \\
Direction $\left({ }^{\circ} \mathrm{N}\right)$ & 112 & $102(111)$ & $111(107)$ & $115(107)$ & $116(122)$ \\
\hline
\end{tabular}

\section{Results}

\section{Bathymetric Change}

The elevation difference between the pre-Hurricane Sandy and the June 2013 bathymetry shows the development of the breach channel and the ebb delta, with substantial erosion of the barrier island where the breach formed and deposition in the nearshore immediately seaward of the breach opening (fig. 8A). The June 2013 survey did not include the flood shoals; therefore, the change map does not include the flood shoals but does capture the ebb shoal, which is relatively symmetrical 8 months after formation. By June 2014, the ebb shoal expanded and became less symmetrical, with an elongation to the west and offshore (fig. 8B).

The June 2014 bathymetry is the first to capture the flood-shoal complex, as well as the main breach channel and ebb delta (fig. 9A). Elevation differences between June 2014 and October 2014 show the shifting of the main channel to the east within the throat and the dynamic nature of channel formation and shoaling within both the ebb delta and flood shoals. The dataset also captures the formation of a spit on the northwestern side of the breach, which is also well documented in the shoreline analysis in the discussion that follows. By May 2015, the main channel within the breach had shifted westward and lengthened, extending farther into Great South Bay and into the ebb shoal where the northeast-southwest-oriented channel connects with a northwest-southeast channel in the flood shoal (fig 9B).

The evolution of the primary channel is shown in a time series of cross-breach profiles from each of the bathymetry datasets (fig. 10). Within the flood shoal, the channel is relatively shallow and stable in position (fig. 10A). In the central portion of the breach (fig.10B), the channel shows a slight eastern migration. The most dynamic portion of the channel is on the seaward side, immediately adjacent to the ebb delta (fig. 10C), where the channel continually migrated westward and shallowed through time. 


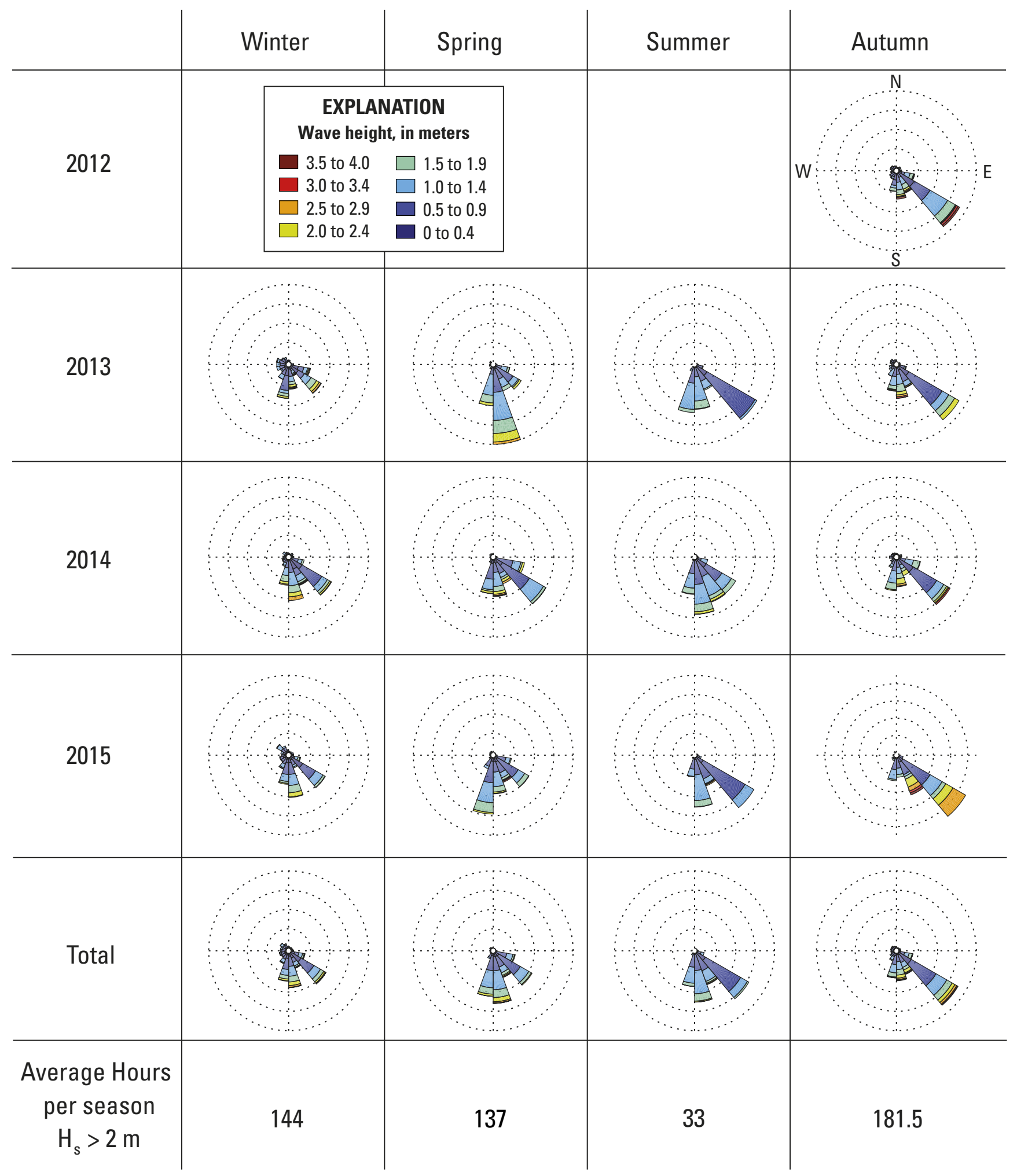

Figure 7. Rose diagrams of significant wave height $\left(\mathrm{H}_{\mathrm{s}}\right)$ and direction from WAVEWATCH III hindcast data, interpolated to the 20-meter isobath offshore of the breach for the period October 1, 2012, to October 31, 2015. The largest waves occurred between autumn and spring, with autumn dominated by large waves out of the southeast, and winter and spring variable with more southerly waves. 


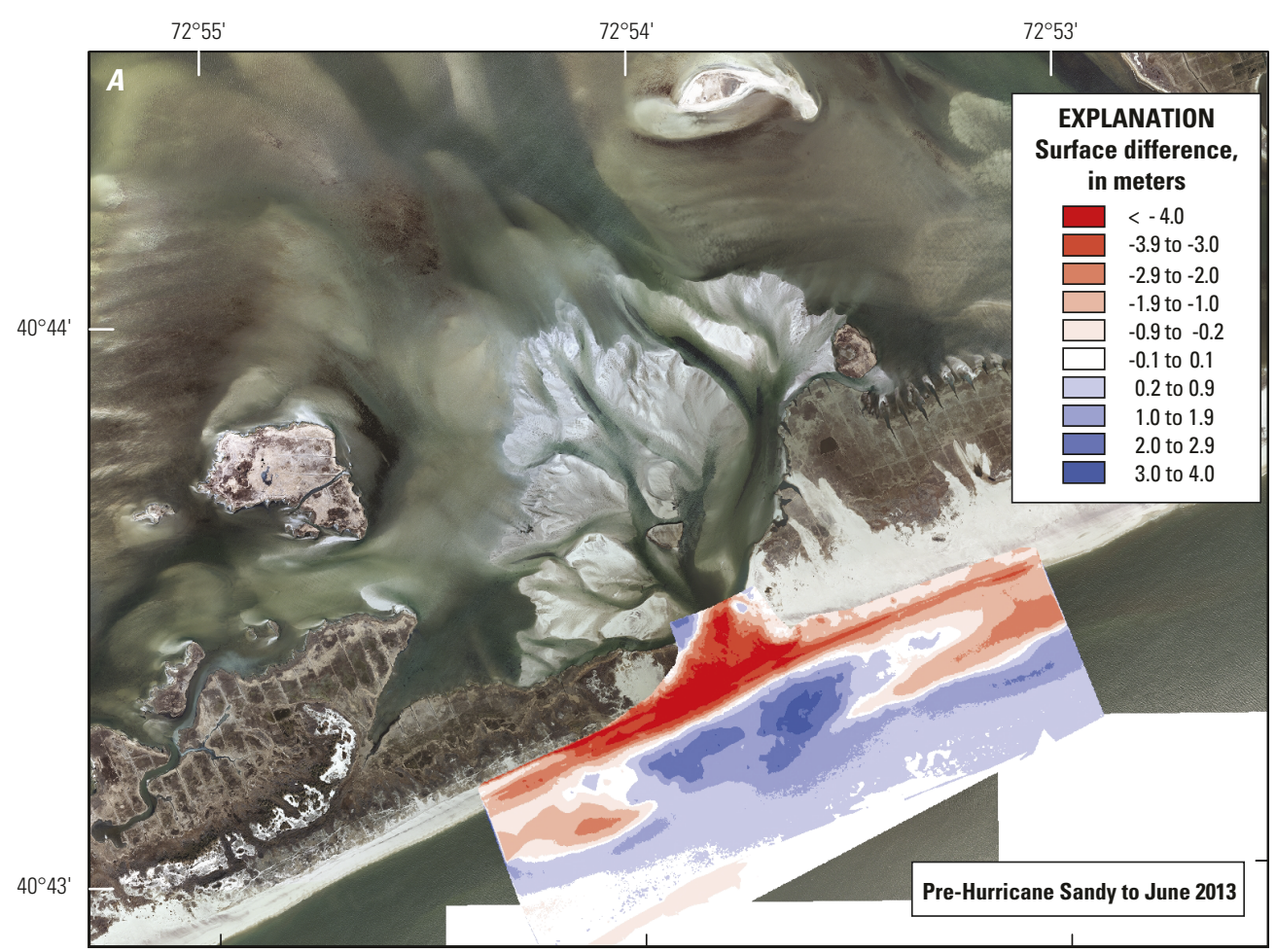

Base from NYS Office of Information Tech Services 2013 Imagery, Suffolk County NY

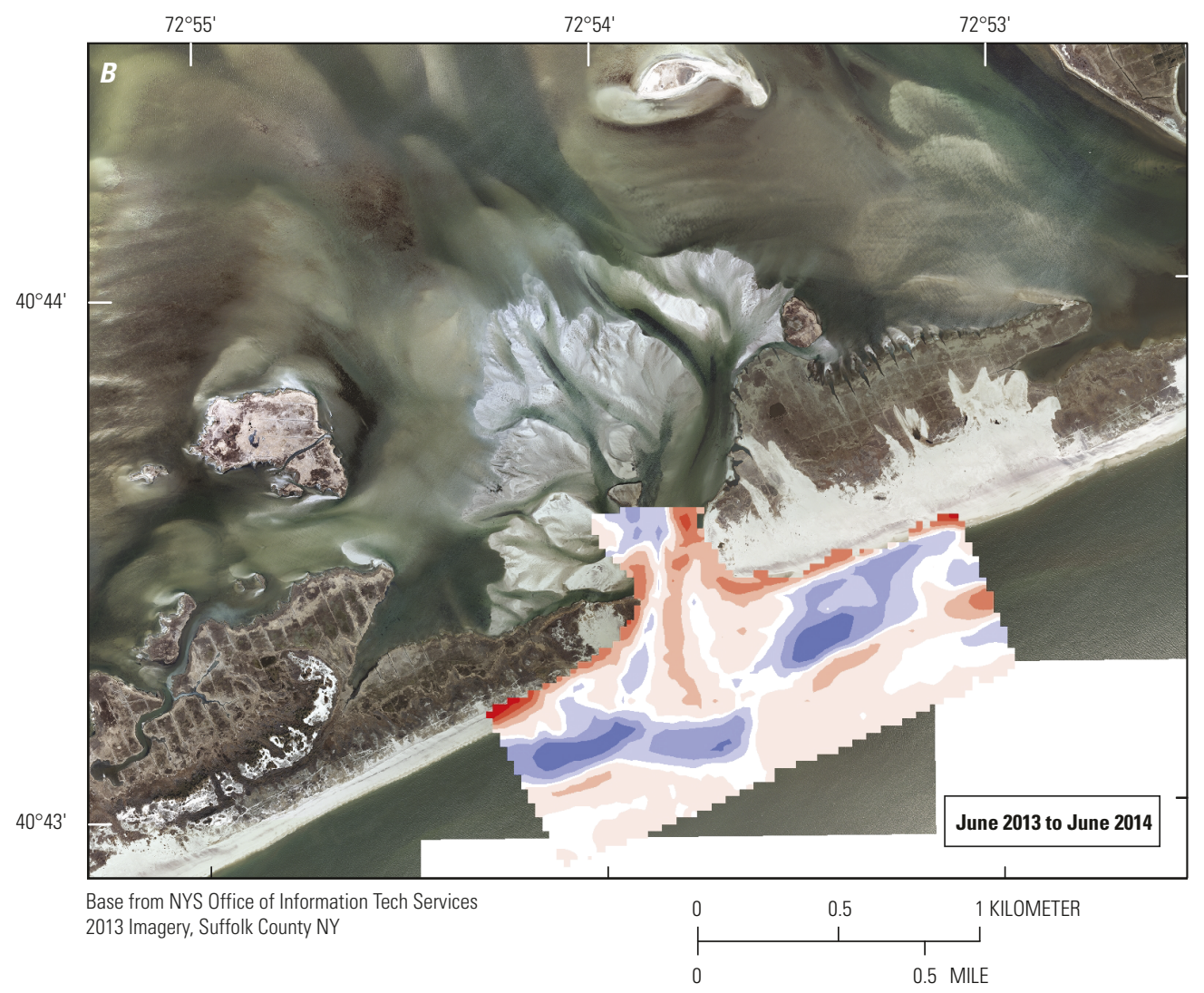

Figure 8. Aerial photographs overlain with elevation difference maps based on the available bathymetric data for the breach: A, pre-Hurricane Sandy to June 2013, no data were collected for the flood shoal; B, June 2013 to June 2014. 


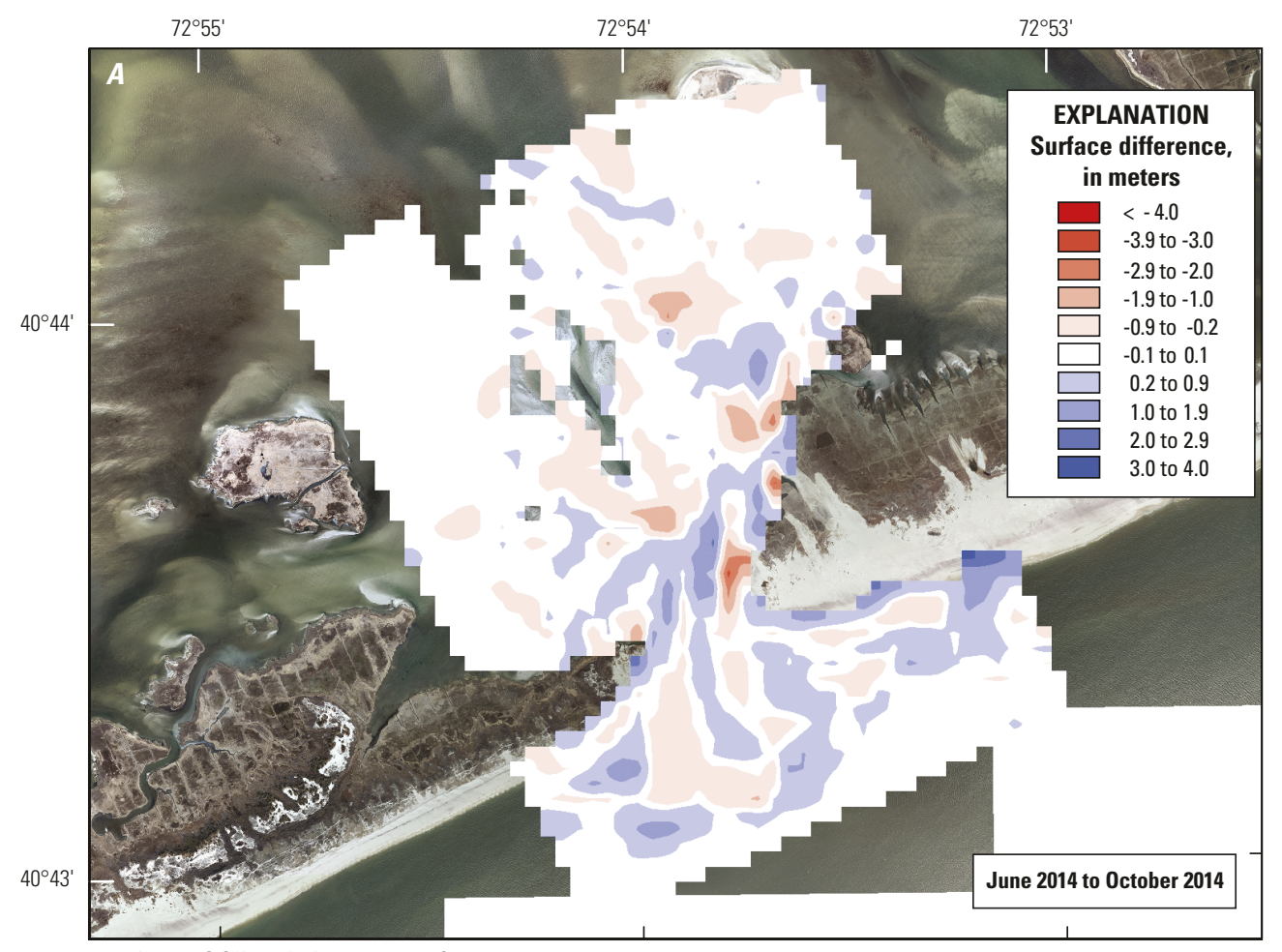

Base from NYS Office of Information Tech Services 2013 Imagery, Suffolk County NY

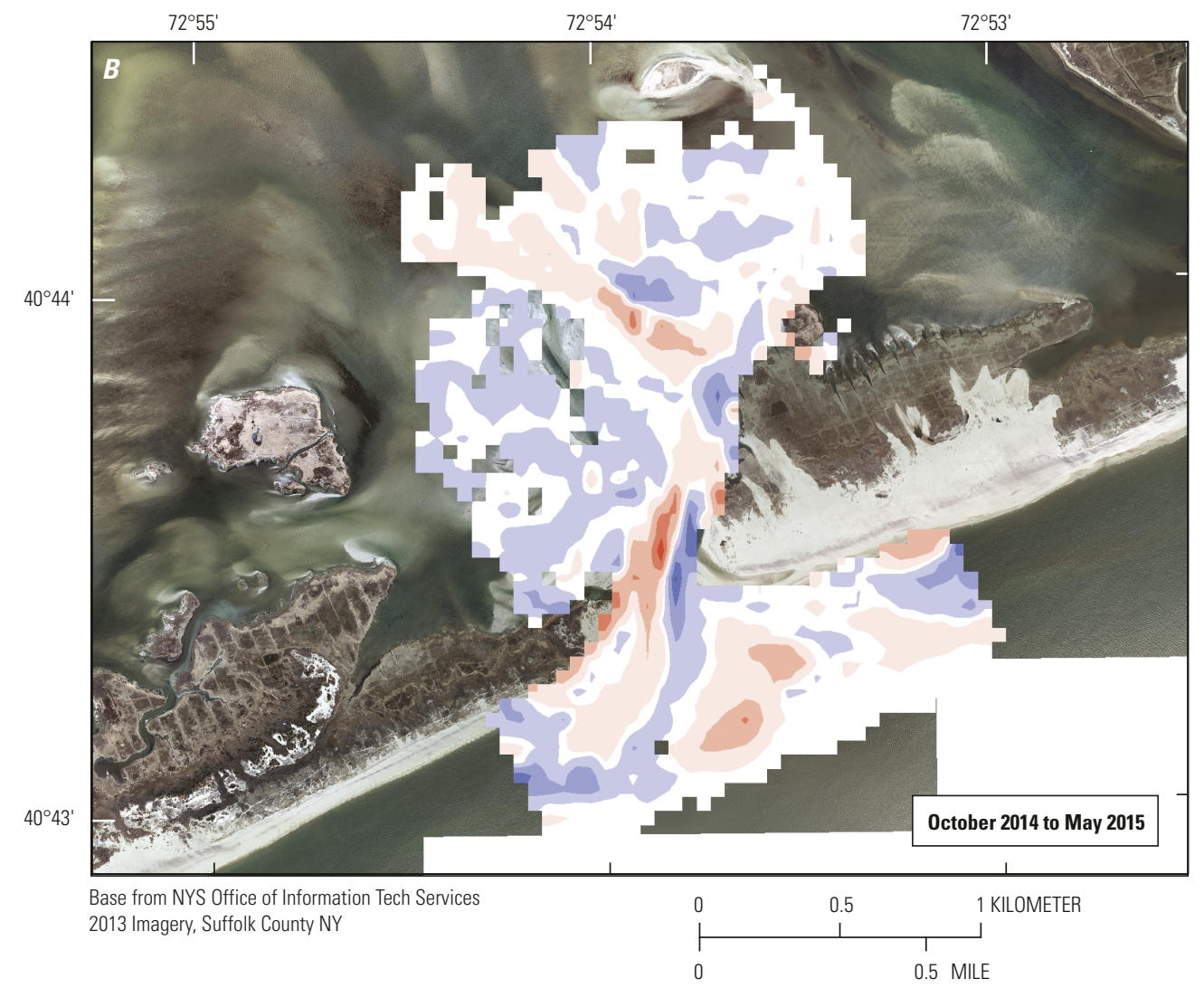

Figure 9. Aerial photographs overlain with elevation difference maps based on the available bathymetric data for the breach: A, June 2014 to May 2015; B, May 2015 to October 2015. Aerial photograph from New York Statewide Digital Orthoimagery Program from 2013 (https://orthos.dhses.ny.gov/). 


\section{Shoreline and Width Change}

The wilderness breach grew rapidly between November 2012 and April 2013, widening from $54 \pm 19 \mathrm{~m}$ on November 6, 2012 (1 week after formation), to $255 \pm 60 \mathrm{~m}$ by April 11, 2013 (fig. 11A). The width increase is primarily a function of westward migration of the western breach shoreline (fig. $11 B$ ). The eastern breach shoreline position changed little during the study period, migrating less than $100 \mathrm{~m}$ to the west (fig. 11C). The western shoreline continued to migrate westward until the winter of 2014, when the main channel throat reached a maximum width of $573 \pm 173 \mathrm{~m}$ on December 29, 2014. From winter 2014 to autumn 2015, the western shoreline oscillated east and west with some seasonal relation. Between the winter of 2014 and November 2015, the breach did not exhibit an overall increase in average width, indicating that a quasi-stable configuration was reached in winter 2014.

\section{Channel Orientation and Spit Length}

Beginning in April 2013 a northeast-southwest-oriented spit started to form on the northwestern side of the breach (fig. 6). The spit exhibited cyclic, seasonal behavior wherein it formed in late winter/ early spring, reached a maximum length in summer to autumn, and rapidly eroded in late autumn or early winter, generally in response to storms (fig. 12A). In 2015, the spit eroded in late summer during Hurricane Joaquin.

The growth of the spit is associated with changes in the orientation of the primary breach channel (fig. 12B). Prior to spit development in the spring of 2013, the orientation of the channel was northnorthwest, roughly perpendicular to the orientation of the barrier island. Through time, when the spit developed, the channel rotated to a northeast-southwest orientation, and when the spit eroded, the channel shifted back to the island-perpendicular orientation.

\section{Wave Climatology}

The wave climate of Fire Island during the study period was characterized by waves propagating to the north and northwest with heights typically less than $1.5 \mathrm{~m}$ (table 2; fig. 7). The highest waves occurred from the autumn to early spring with smaller waves during summer. Wave periods were relatively consistent throughout the year, and the wave direction was more northward during the winter and north-northeast during the other seasons.
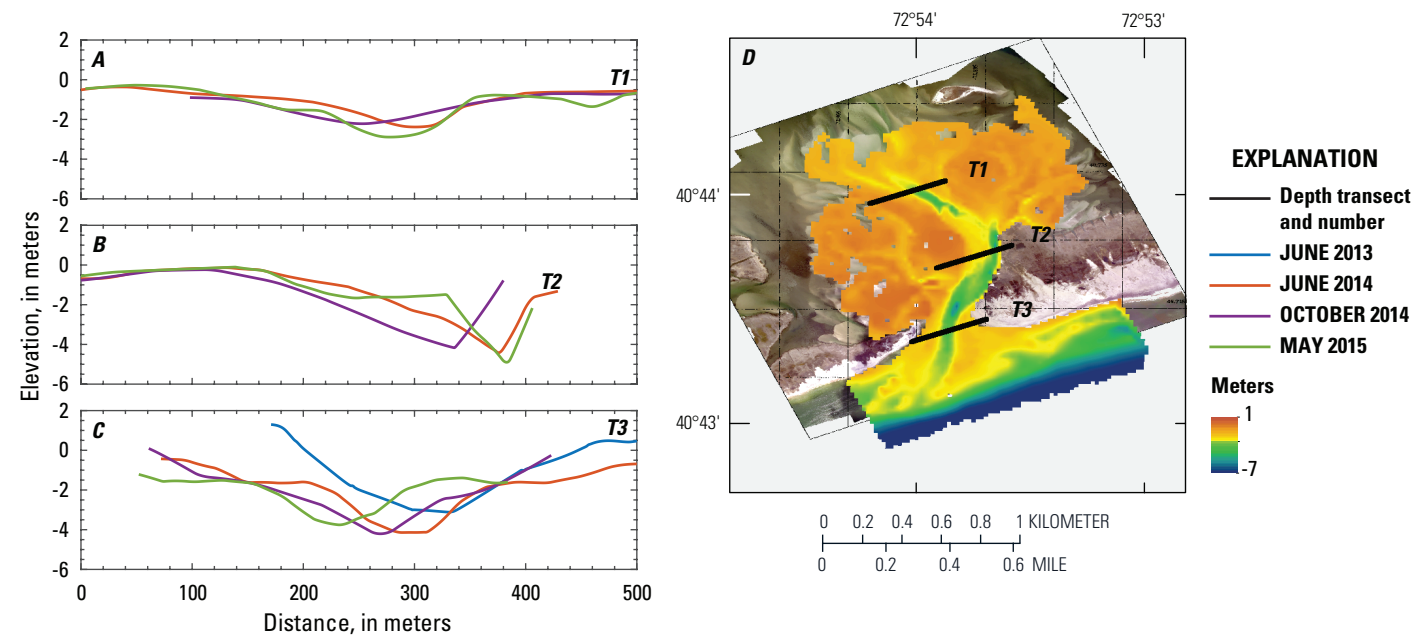

Figure 10. Plots showing cross-breach profiles for the $A$, northern, $B$, central, and $C$, southern portions of the breach channel with $D$, profile locations shown. 

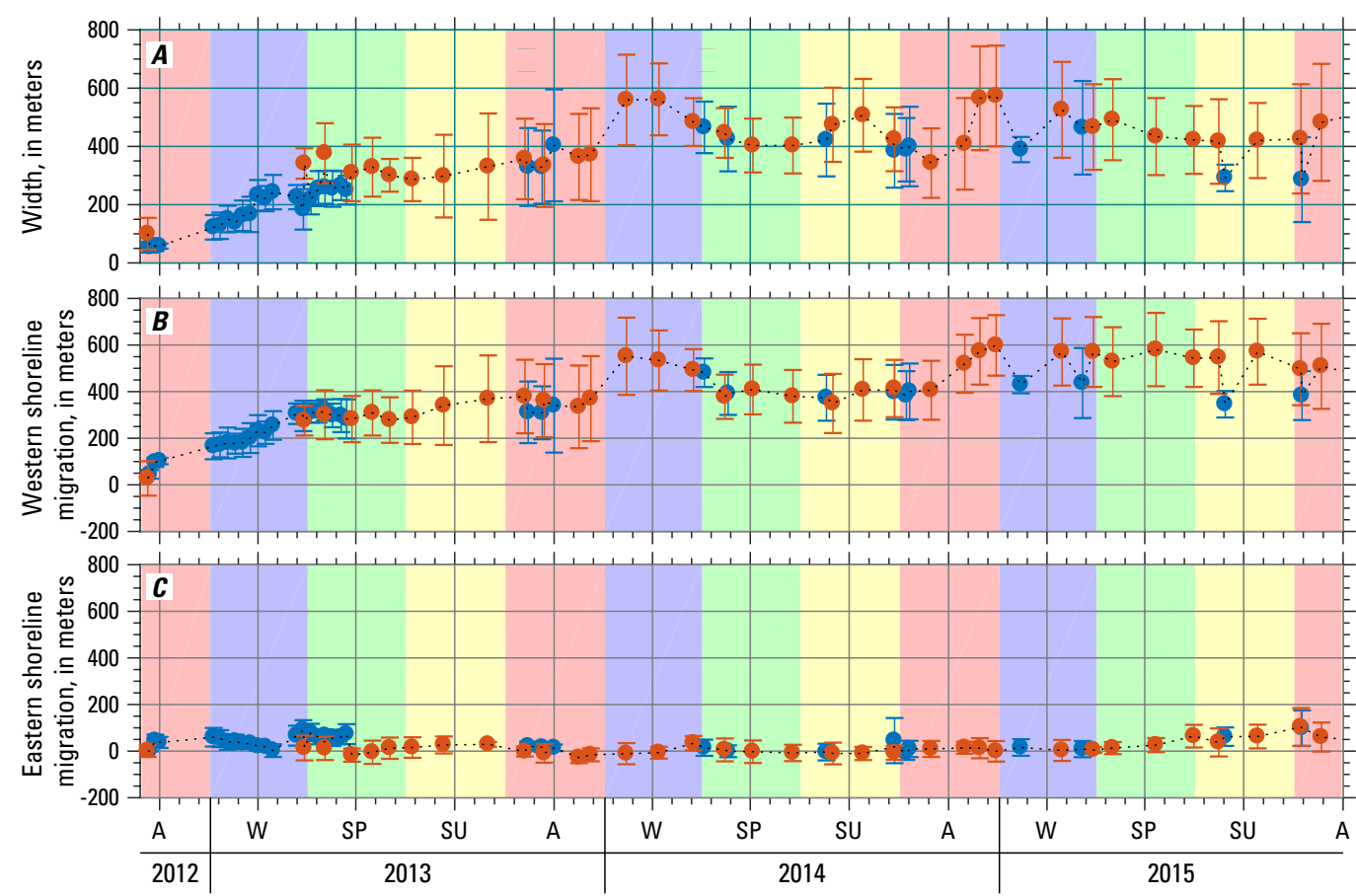

Figure 11. Plots showing $A$, breach width and $B$, net western shoreline migration and $C$, eastern shoreline migration from November 2012 to November 2015. Colors highlight the season with winter (W) in blue, spring (SP) in green, summer (SU) in yellow, and autumn $(\mathrm{A})$ in red. Blue dots represent data collected using field surveys, and red dots represent metric-derived data obtained from aerial photographs. The black dashed line shows the trend using both aerial and ground-based surveys, and error bars are shown by vertical lines associated with each point.

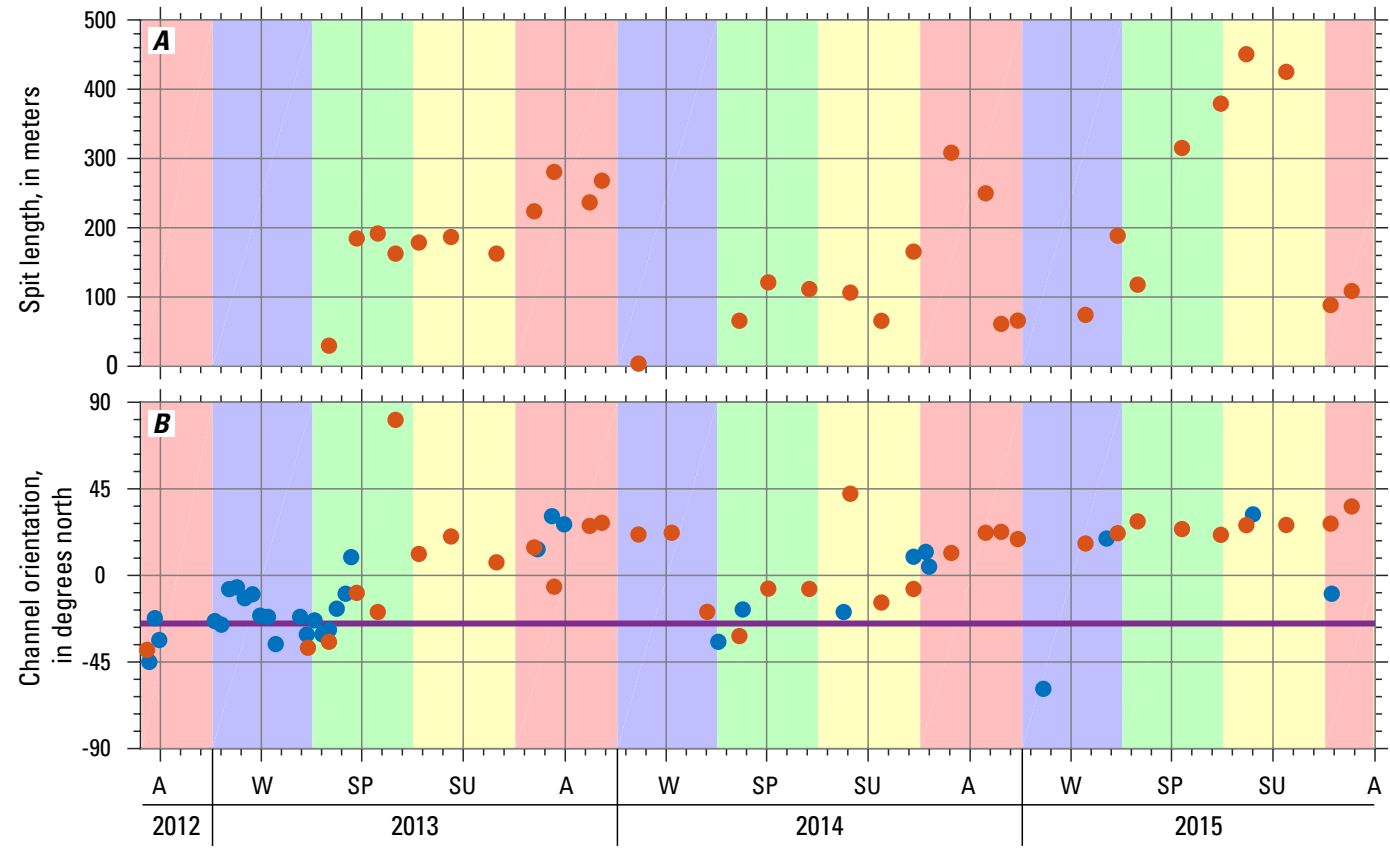

Figure 12. The time series of $A$, spit length and $B$, breach channel orientation, which indicates that the presence of the spit on the northwest side of the breach is closely associated with the orientation of the main breach channel and that it oscillates seasonally. Colors highlight the season with winter (W) in blue, spring (SP) in green, summer (SU) in yellow, and autumn (A) in red. The purple line shows the orientation perpendicular to the barrier island shoreline. 


\section{Discussion and Summary}

The wilderness breach initially formed in a north-northeast orientation, essentially orthogonal to the barrier island and in the general location of the Old Inlet breach, which was open for more than 60 years in the 1800s (Leatherman and Allen, 1985). The location and orientation of the breach followed the path of an elevated boardwalk that connected the beachside of the island to the bayside where a manmade embayment existed (fig. $3 A, B$ ). The center of the breach channel corresponded to an area of higher elevation dunes than surrounding areas (fig. 3C), and we speculate that its formation may be due to a combination of factors, including the narrowness of the island at this location, lower flow friction beneath the boardwalk due to the lack of vegetation, and the increased erodibility of the Old Inlet channel-fill substrate. The breach widened and migrated westward through the spring of 2013, with substantial movement likely in response to high wave energy out of the southeast. Wave heights greater than $3 \mathrm{~m}$ were observed during seven nor'easter storms during the winter and spring following Hurricane Sandy (Hapke and others, 2013) (figs. 7, 11). Westward channel migration is driven by erosion of the western side of the breach (fig. 11B) with the breach channel remaining oriented orthogonally to the island. The eastern side of the breach was remarkably stable through the period of the analysis. Although no core data have been published at the time of this report, preliminary results from field data collection and visual inspection in the walls of the breach channel indicate the presence of multiple layers of lagoonal (blue) clay interbedded with sand layers on the eastern side that are not present on the western side and may influence the stability of the eastern side by making it more resistant to erosion.

Following the winter of 2013-14, the trend of increasing width and westward migration largely ceased, indicating the breach had reached a state of quasi-equilibrium. The western side began a seasonal eastward and westward oscillation through the recurring formation and erosion of a spit on the northwest side and seasonal variation of the channel orientation.

The most significant morphologic changes (changes in width and orientation) typically occurred during the autumn and winter, when high waves were larger and predominantly out of the southeast (fig. 7) and were manifested in the dynamic western side of the breach that changed in response to spit formation and erosion. The spit appeared to influence the channel orientation within the breach throat and played a controlling role in the development of flood channels. Prior to development of the spit, numerous flood channels were present at various orientations. When the spit formed and extended into the bay, the western flood channels became cut off and slowly in-filled with sediment, diverting more discharge to the eastern side of the channel and causing a clockwise rotation of the channel. By necessity, this process diverted more flow into the eastern channel and reduced the efficiency of the flow by creating a highly sinuous channel. The cycles of spit formation and erosion, and rotation of channel orientation, demonstrate the nested dynamics within an overall quasi-stable system, but do not lend information on what processes may eventually lead to closing of a breach.

The wilderness breach at Fire Island is a highly dynamic and complex system, driven by feedbacks between wave and wind forcing, and tidal flow (not discussed in this analysis). The data summarized in this report provided the foundation for modeling efforts of the breach (van Ormondt and others, 2015), and the analyses described herein provide insight into the physical evolution of a breach during 3 years of monitoring. 


\section{References Cited}

Brownell, A., Hapke, C., Spore, N., and McNinch, J., 2014, Bathymetry of wilderness breach at Fire Island, New York, June 2013: U.S. Geological Survey Data Series 914, accessed February 22, 2015, at https://doi.org/10.3133/ds914.

Hapke, C.J., Brenner, O.T., Hehre, R.E., and Reynolds, B.J., 2013, Coastal change from Hurricane Sandy and the 2012-13 winter storm season-Fire Island, New York: U.S. Geological Survey Open-File Report 2013-1231, 37 p., accessed August 28, 2013, at https://pubs.usgs.gov/of/2013/1231/.

Hapke, C.J., Brenner, O.T., and Henderson, R.E., 2015, Quantifying the geomorphic resiliency of barrier island beaches: Proceedings Coastal Sediments 2015, San Diego, May 11-15, 2015, accessed October 20, 2015, at https://doi.org/10.1142/9789814689977_0249.

Hapke, C.J., Lentz, E.E., Gayes, P.T., McCoy, C.A., Hehre, R.E., Schwab, W.C., and Williams, S.J., 2010, A review of sediment budget imbalances along Fire Island, New York - Can nearshore geologic framework and patterns of shoreline change explain the deficit?: Journal of Coastal Research, v. 26, p. 510-522. [Also available at https://doi.org/10.2112/08-1140.1.]

Hapke, C.J., Plant, N.G., Henderson, R.E., Schwab, W.C., and Nelson, T.R., 2016, Decoupling processes and scales of shoreline morphodynamics: Marine Geology, v. 381, p. 42-53, accessed September 12, 2016, at https://doi.org/10.1016/j.margeo.2016.08.008.

Henderson, R.E., Hapke, C.J., Brenner, O.T., and Reynolds, B.J., 2017, Hurricane Sandy beach response and recovery at Fire Island, New York-Shoreline and beach profile data, October 2012 to September 2016: U.S. Geological Survey data release, accessed April 22, 2017, at https://doi.org/10.5066/ F7G15Z17.

Kratzmann, M.G., and Hapke, C.J., 2012, Quantifying anthropogenically driven morphologic changes on a barrier island-Fire Island National Seashore, New York: Journal of Coastal Research, v. 28, p. 76-88. [Also available at https://doi.org/10.2112/JCOASTRES-D-10-00012.1.]

Leatherman, S.P., and Allen, J.R., 1985, Geomorphologic analysis of south shore of Long Island barriers, New York: Report to U.S. Army Corps of Engineers, New York District, New York. [Paper copy available from the St. Petersburg Coastal and Marine Science Center.]

Lentz, E.E., and Hapke, C.J., 2011, Geologic framework influences on the geomorphology of an anthropogenically modified barrier island-Assessment of dune/beach changes at Fire Island, New York: Geomorphology, v. 126, p. 82-96. [Also available at https://doi.org/10.1016/j. geomorph.2010.10.032.]

Lentz, E.E., Hapke, C.J., Stockdon, H.F., and Hehre, R.E., 2013, Improving understanding of near-term barrier island evolution through multi-decadal assessment of morphologic change: Marine Geology, v. 337, p. 125-139. [Also available at https://doi.org/10.1016/j.margeo.2013.02.004.]

National Oceanic and Atmospheric Administration, 2012, Station 44025 (LLNR 830)—Long Island-30 nm South of Islip, NY: Stennis Space Center, Miss., National Data Buoy Center website, accessed October 20, 2015, at http://www.ndbc.noaa.gov/station_page.php?station=44025.

Nelson, T.R., Miselis, J.L., Hapke, C.J., Brenner, O.T., Henderson, R.E., Reynolds, B.J., and Wilson, K.E., 2017a, Bathymetry data collected in October 2014 from Fire Island, New York-The wilderness breach, shoreface, and bay: U.S. Geological Survey Data Series 1034, accessed March 25, 2017, at https://doi.org/10.3133/ds1034. 
Nelson, T.R., Miselis, J.L., Hapke, C.J., Brenner, O.T., Henderson, R.E., Reynolds, B.J., Wilson, K.E., 2017b, Coastal bathymetry data collected in May 2015 from Fire Island, New York-Wilderness breach and shoreface: U.S. Geological Survey Data Series 1049, accessed May 15, 2017, at https://doi. org/10.3133/ds1049.

Nelson, T.R., Miselis, J.L., Hapke, C.J., Wilson, K.E., Henderson, R.E., Brenner, O.T., Reynolds, B.J., and Hansen, M.E., 2016, Coastal bathymetry data collected in June 2014 from Fire Island, New YorkThe wilderness breach and shoreface: U.S. Geological Survey Data Series 1007, accessed December 10, 2016, at https://doi.org/10.3133/ds1007.

Schwab, W.C., Baldwin, W.E., Denny, J.F., Hapke, C.J., Gayes, P.T., List, J.H., and Warner, J.C., 2014, Modification of the Quaternary stratigraphic framework of the inner-continental shelf offshore of Fire Island by Holocene marine transgression-An example offshore of Fire Island, New York: Marine Geology, v. 355, p. 346-360. [Also available at https://doi.org/10.1016/j.margeo.2014.06.011.]

Schwab, W.C., Baldwin, W.E., Hapke, C.J., Lentz, E.E., Gayes, P.T., Denny, J.F., List, J.H., and Warner, J.C., 2013, Geologic evidence for onshore sediment transport from the inner continental shelfFire Island, New York: Journal of Coastal Research, v. 29, p. 526-544. [Also available at https://doi. org/10.2112/JCOASTRES-D-12-00160.1.]

van Ormondt, Maarten, Hapke, C.J., Roelvink, Dano, and Nelson, T.R., 2015, The effects of geomorphic changes during Hurricane Sandy on water levels in Great South Bay: Proceedings Coastal Sediments 2015, San Diego, May 11-15, 2015. [Also available at https://doi.org/10.1142/9789814689977_0221.]

Warner, J.C., List, J.H., Schwab, W.C., Voulgaris, George, Armstrong, Brandy, and Marshall, Nicole, 2014, Inner-shelf circulation and sediment dynamics on a series of shoreface-connected ridges offshore of Fire Island, NY: Ocean Dynamics, v. 64, p. 1767-1781, accessed October 30, 2016, at https://doi. org/10.1007/s10236-014-0781-y.

Wright, C.W., Kranenburg, C.J., Klipp, E.S., Troche, R.J., Fredericks, Xan, Masessa, M.L., and Nagle, D.B., 2014, EAARL-B coastal topography_Fire Island, New York, pre-Hurricane Sandy, 2012, seamless (bare earth and submerged): U.S. Geological Survey Data Series 888, accessed November 4, 2014, at https://doi.org/10.3133/ds888. 


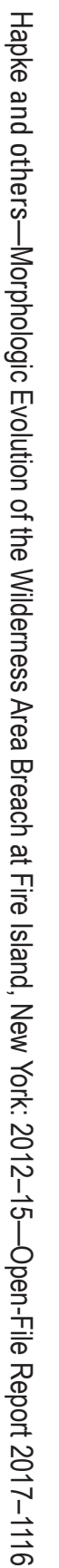

